\title{
BUDIKDAMBER (FISH FARMING IN BUCKETS) AS A FOOD SECURITY SOLUTION IN SIMOMULYO BARU SUKOMANUNGGAL SURABAYA
}

\author{
Della Anugrah Heni' ${ }^{1}$, M. Shodiqul Anwar ${ }^{2}$, Nihlatul Falasifah ${ }^{3}$, \\ Vera Arida $^{4}$, Ummy Chairiyah ${ }^{5}$ \\ ${ }^{12345}$ Sunan Ampel State Islamic University, Surabaya \\ 11dellaanugrahh@gmail.com, 2shodiqulanwar307@gmail.com, ${ }^{3}$ nihlatul.falasifah@uinsby.ac.id, \\ 4vera.arida@uinsby.ac.id, 5ummy.chairiyah@uinsby.ac.id
}

\begin{abstract}
Fish farming in buckets or popularly known as Budikdamber can be an alternative as a food security solution especially during the current Covid-19 pandemic. It can be a solution for community who have limited land for fish and vegetable cultivation. The work system of Budikdamber is cultivating fish and vegetables in one bucket which is simple aquaponic system (polyculture of fish and vegetables). The result of this Budikdamber can harvest two types of commodities simultaneously in the form of catfish and vegetables. Community service was carried out in Simomulyo Baru Village, Sukomanunggal District, Surabaya, in March up to April 2021. The objectives of this community service are providing information and giving training on how to use the narrow land for fish and vegetable cultivation in buckets so that people can maintain food security during this pandemic. People in Simomulyo feel the benefits of Budikdamber because of the presence of catfish as animal protein and fresh vegetables that can be harvested at the harvest time. It can economically help reduce the risk of kitchen costs and it can be a solution for food security from the local community.
\end{abstract}

Keywords: Budikdamber, Community Service, and Food Security.

Abstrak: Budidaya ikan dalam ember atau yang populer disebut sebagai Budikdamber dapat menjadi salah satu alternatif untuk solusi ketahanan pangan terutama di masa pandemi Covid-19 seperti saat ini. Ini dapat menjadi solusi bagi masyarakat yang memiliki keterbatasan lahan untuk budidaya ikan dan tanaman. Budikdamber merupakan salah satu teknologi tepat guna yang mudah dilakukan oleh masyarakat di rumah masing-masing dengan modal yang relatif kecil dan mampu mencukupi kebutuhan gizi masyarakat. Sistem kerja dari Budikdamber adalah membudidayakan ikan dan sayuran dalam satu ember yang merupakan system akuaponik (polikultur ikan dan sayuran). Hasil dari Budikdamber ini bisa memanen dua jenis komoditi sekaligus berupa ikan biasanya menggunakan ikan lele dan sayuran biasanya menggunakan kangkung. Pengabdian kepada masyarakat dilaksanakan di Desa Simomulyo Baru, Kecamatan Sukomanunggal, Surabaya, pada bulan Maret sampai dengan April 2021. Tujuan dari pengabdian masyarakat ini adalah memberikan informasi dan memberikan pelatihan tentang cara memanfaatkan lahan sempit untuk budidaya ikan dan sayuran dalam ember sehingga masyarakat bisa menjaga ketahanan pangan di masa pandemi seperti sekarang ini. Masyarakat di Simomulyo merasakan manfaat budikdamer karena keberadaan ikan dan sayuran yang bisa dipanen kapanpun pada saat waktunya memanen. Secara ekonomi dapat membantu mengurangi biaya rumah tangga sehari-hari dan dapat menjadi solusi ketahanan pangan bagi masyarakat setempat.

Kata kunci: Budikdamber, Pengabdian Masyarakat, dan Ketahanan Pangan. 


\section{A. Introduction}

Simomulyo Baru is a village in the Sukomanunggal district, Surabaya City, East Java Province, Indonesia. Simomulyo Baru Village has an extensive area of $2 \mathrm{~km}^{2}$. Based on the usage of land, there is $\mathbf{1 7 2 . 5}$ hectares used for non-agricultural land, but there is no rice fields and nonrice fields ${ }^{1}$. The distance between Simomulyo Village and Sukomanunggal District is $1 \mathrm{~km}$. This area is located on a strategic plain and has a tropical climate. According to the division of regional planning, Simomulyo is divided into 12 community units consisting of 98 neighborhood units. The population of Simomulyo Baru Village is 42.248 people consisting of 21.263 men and 20.985 women. So that the population density of Simomulyo Baru Village is 21.124 people $/ \mathrm{km}^{2}$, two until four times denser than other villages in Sukomanunggal district ${ }^{2}$.

Limited land is indicated with the unavailability of rice fields and non-rice fields while the dense population becomes another problem related to the increasing demand for vegetable and animal protein. Urban areas, especially metropolitan cities, characterized by high population density, most of the land is used for settlements and infrastructure development, with limited green open space ${ }^{3}$. Surabaya as a city of trade and service has relatively small contribution in agricultural sector considering the limited agricultural land and the occurrence of land conversion in urban areas. This is also due to the shift of farmers' livelihoods to other sectors that are more promising from an economic perspective. Administratively, the largest distribution of agricultural land is in the West Surabaya and East Surabaya areas with the main crops produced are rice and corn. In addition to food crops, agriculture in Surabaya also produces vegetables and fruits. The types of vegetables produced are kale, mustard greens, spinach, tomatoes, and garbis. Meanwhile, the types of fruits produced are guava, guava, mango, banana, and so on. The number of fish production in Surabaya from 2014 to 2017 is relatively fluctuating and tends to decrease 4 . In 2013, the total fish production in Surabaya was 15832.9 tons and in 2014 it decreased to 7992.89 tons $^{5}$. Then, in 2015 and 2016, fish production in Surabaya was 8114.09 tons and 8114.43 tons, respectively ${ }^{6}$. In Surabaya, the largest types of marine fish are crab, white shrimp, crab, and mullet. The most common types of inland fish are milkfish, white shrimp, and vannamei shrimp.

Fish are a rich source of protein, fatty acids, vitamins such as D and B2 (riboflavin). Fish is also rich in phosphorus and calcium. It is a great source of minerals such as iron, zinc, iodine, magnesium, and potassium. In another word, fish has been an important source of protein and other nutrients for humans. Many species of fish are consumed as food by human around the world. One of the fish species is catfish which one of the most common culinary fish in the world. These fish live in freshwater environments and is usually found in Asia, Africa, Europe and Americas. Catfish has an impressive and excellent nutrition profile Despite being low in calories, the fish has a wide range of nutrients with high amounts of some essential vitamins. Catfish contains small amounts of fat and contains omega- 3 fatty acids. It has white flesh and relatively lean and contains a low amount of mercury. According to research conducted by the Food and Drug Administration (FDA) from 1990 until 2012, catfish only contains a mean average mercury content of $0.024 \mathrm{PPM}^{7}$. Catfish is extremely protein-dense and offers 26.41 grams of protein for

\footnotetext{
1 "Kecamatan Sukomanunggal dalam Angka 2019."

2 Ibid.

3 Ipanna Enggar Susetya and Zulham Apandy Harahap, "Aplikasi Budikdamber (Budidaya Ikan Dalam Ember) Untuk Keterbatasan Lahan Budidaya Di Kota Medan,” ABDIMAS TALENTA: Jurnal Pengabdian Kepada Masyarakat 3, no. 2 (2018): 416-420, https://talenta.usu.ac.id/abdimas/article/view/4165. 4 Statistik Sektoral Kota Surabaya 2017 (Surabaya, 2017), https://www.surabaya.go.id/id/berita/49832/statistik-sektoral-kota-surabaya. 5 Ibid.

${ }^{6}$ Ibid.

${ }^{7}$ Mercury Levels in Commercial Fish and Shellfish (1990-2012) (Silver Spring, Maryland, 2014), https://www.fda.gov/food/metals-and-your-food/mercury-levels-commercial-fish-and-shellfish-19902012.
} 
only 150 calories $^{8}$. It is an excellent source of Vitamin D which Vitamin D has many important roles within the body to enhance our immune system. Another great benefit of catfish is so rich in B vitamins. In particular, it is a great source of vitamin B12 where vitamin B12 is one of the most common dietary deficiencies in the world ${ }^{9}$. Overall, catfish has essential nutrients with several key benefits.

Vegetables contain healthful vitamins, minerals, and dietary fiber. One type of vegetable is kale. It contains fiber, minerals, antioxidants, vitamins, and various bioactive compounds. Kale is high in vitamin $\mathrm{A}$, vitamin $\mathrm{C}$, and vitamin $\mathrm{K}^{10}$. It also contains large amounts of vitamin $\mathrm{B} 6$, copper, calcium, magnesium, potassium, and manganese. Kale and other leafy greens are also high in various bioactive compounds, including indole-3-carbinol and isothiocyanates which have been known to fight cancer.

As we know that food is very important in human life and without food humans cannot live properly. Food is a substance that is eaten by humans to get nutrients which are processed and converted into energy. Food security is certainly the key to facing the threat of food crises in the future. Various efforts have been made by Indonesian government to improve food security such as the provision of subsidized fertilizers, construction of irrigation infrastructure, provision of seeds, and so on. Availability, access (affordability), and quality (safety) of food for 270,20 million people in Indonesia must be fulfilled by Indonesian government. It is necessary to design appropriate food management policies in accordance with empirical conditions in the field especially during Covid-19 pandemic. The Covid-19 pandemic, which is still ongoing until now, has awakened humanity to prepare various efforts and breakthroughs to face various threats of crises, especially the food crisis. In other words, this pandemic can be a threat to food security in Indonesia. Food is a strategic issue because it is closely related to the social, economic, and political dimensions of the people in terms of production, distribution, and consumption. Food is a very strategic and complex affair whose existence will determine the future of the nation. The national food system involves agricultural systems, industrial systems, logistics, warehousing systems, distribution, trade systems, and food institutional systems. Each of these systems is supported by various sub-systems and components.

Pandemic affects on farm activities and its distribution. This will also affect on agricultural production activities as well as food availability, and will further affect on food security. Food security will affect to nutritional status and nutritional status can affect food policy by the government. Food security will be achieved if there is food availability. The food availability will also be achieved if there is agricultural production. However, agricultural production is now declining, especially in the Surabaya area. The decline in food production in Surabaya is caused by the narrower area of productive agricultural land as a result of conversion of functions, and also the global issue of increasing land degradation in developing countries. Moreover, problems that occur in marine waters, namely pollution and ecosystem damage triggered the effort to solve this issue in order to fulfill the needs of people to consume fish. Reviewing this issue, it is needed to provide food self-sufficiency solution in Simomulyo Baru village, Sukomanunggal district, Surabaya city through the development of integrated cultivation system technology between fish breeding and rearing systems with plant production systems. This land cultivation

\footnotetext{
${ }^{8}$ R A Hall et al., "National Marine Fisheries Service Survey of Trace Elements in the Fishery Resources," NOAA technical report;NMFS SSRF-721 (Rockville, Md.: Dept. of Commerce, National Oceanic and Atmospheric Administration, National Marine Fisheries Service, 1978), file://catalog.hathitrust.org/Record/102424037.

${ }_{9}^{9}$ Michael Joseph, "Catfish 101: Nutrition Facts and Health Benefits," last modified 2019, accessed September 2, 2021, https://www.nutritionadvance.com/catfish-nutrition-benefits/.

${ }^{10}$ Autumn Enloe, "The 13 Healthiest Leafy Green Vegetables," last modified 2018, accessed September 2, 2021, https://www.healthline.com/nutrition/leafy-green-vegetables.
} 
is called Budikdamber ${ }^{11}$. According to Luckyta Anjasari, the conditions of limited land and the increasing number of residents become a separate problem for people in urban and rural areas, especially for lower middle-class people. Considering that lower-middle class people living in cities have limited areas of land for agricultural cultivation, therefore they only act as consumers. People living in cities must find root cause of these problems and nutritional needs that should be balanced.

Another issue that strikes Simomulyo Baru Village is regarding the Covid-19 pandemic. As of 5 August 2020, the number of confirmed COVID-19 cases was 253 in Sukomanunggal District and 76 positive confirmed cases in Simomulyo Baru Village, besides that, the number of positive confirmed cases in the Simomulyo Baru Village got first rank with the highest cases in the Sukomanunggal district ${ }^{12}$. This pandemic affected the economy of people that live in cities and villages. Minister of Manpower, Ida Fauziyah mentioned that the number of workers affected by layoffs (PHK) reached 2.9 million, give highest contribution on unemployment rate in Indonesia ${ }^{13}$. This condition supposed resident of Simomulyo Baru village to live independently and always be productive within limited land and economic caused by the pandemic. The study results conducted by Akbar et al revealed that Budikdamber is suitable to be applied as a strategy to strengthen food security and the economy of people in Brebes Regency in the midst of Covid-19 pandemic ${ }^{14}$. People who has been success with the bukdidamber technique were able to create business opportunities and increased income during Covid-19 pandemic ${ }^{15}$.

Fish farming in buckets or more popularly known as Budikdamber or in Indonesian acronym "Budidaya Ikan dalam Ember" is a potential solution for aquaculture and agriculture in a narrow space with an efficient water use. This Budikdamber is currently viral because many people were active and staying at home during the Covid-19 pandemic. Budikdamber is suitable for urban areas with minimal land and want to cultivate at home. This method has several advantages, one of them is easy to apply in respective house with low budget, which finally able to meet their nutritional needs of Simomulyo Baru Village community.

Budikdamber is also a complete method for fish farming and growing vegetables in one medium, namely a bucket. The work system of Budikdamber is cultivating fish and vegetables in one bucket or it usually known as an aquaponics system (polyculture of fish and vegetables). This is the integration of recirculating aquaculture and hydroponics in one production system. In another word, Budikdamber is a simple aquaponic for household purpose. Budikdamber is not as complicated as aquaponics which requires pumps and filters which ultimately require electricity, large land, expensive, and complicated method. Budikdamber actually has benefits such as saving water, zero waste, easy maintenance, without chemicals, does not require electricity, water spinach plants can be consumed daily, high public interest in consuming catfish, affordable capital, easy maintenance and food security solution for community. Therefore, the recent study desirable to implement Budikdamber as a Food Security Solution in

\footnotetext{
${ }^{11}$ Ninuk Purnaningsih et al., "Diseminasi Budidaya Ikan Dalam Ember Sebagai Solusi Kegiatan Budidaya Di Lahan Sempit ( Dissemination of Aquaculture in The Buckets as Solutions for Cultivation Activities in Narrow Lands )" 2 (2020): 112-120.

12 “Peta Dan Visualisasi Data Covid-19," last modified 2021, accessed August 5, 2021, https://lawancovid19.surabaya.go.id/.

13 Adhi Wicaksono, "Kemenaker Sebut 2,9 Juta Pekerja Dirumahkan Dan Kena PHK," CNN Indonesia, May 1, 2021, https://www.cnnindonesia.com/ekonomi/20200501182722-92-499300/kemenaker-sebut-29juta-pekerja-dirumahkan-dan-kena-phk.

${ }^{14}$ Akbar Syaifariz et al., "Budikdamber Sebagai Stategi Penguatan Ketahanan Pangan Dan Perekonomian Masyarakat Kabupaten Brebes Di Tengah Pandemi" (n.d.).

15 Sherina Annis, Dewi Saputri, and Dessy Rachmawatie, "Budidaya Ikan Dalam Ember: Strategi Keluarga Dalam Rangka Memperkuat Ketahanan Pangan Di Tengah Pandemi Covid-19 Fish Culture in a Bucket: Family Strategy in Order to Strengthen Food Security in the Covid-19 Pandemic Period" 2, no. 1 (2020): 102-109.
} 
Simomulyo Baru, Sukomanunggal District, Surabaya City, Indonesia. We hope that it can be an effort to assist the Indonesian government in improving food security.

\section{B. Theoretical Studies}

According to research conducted by Purnaningsih et al (2020), fish are aquatic animals which spend $80 \%$ of their lives in water, to grow and thrive ${ }^{16}$. Fish is a useful food source because it has protein, fat, vitamins and minerals. However, fish has an excesscive amounts of omega- 3 and omega- 6 which needed by children. Furthermore, Purnaningsih et al explained that fish meat does not cause cholesterol and high blood pressure ${ }^{17}$. According to Kordi (2012) in Saputri (2020) there are several species of catfish, namely Clarias batrachus, C. leiacanthus, C. maladerma, C. Nieuhofi, C. Teijsmani, and C. gariepinus. One of the six catfish species found in Indonesian waters is the local species (clarias batrachus) which has been cultivated for a long time ${ }^{18}$. Local catfish cultivation started in 1975 at Blitar, East Java and around 1980 was cultivated in pairs at Jagakarsa area, South Jakarta ${ }^{19}$.

Furthermore, Saputri and Rachmawatie explained that in the fish farming business, water quality is one of the important factors that affect the life sustainability of cultivated fish ${ }^{20}$. Catfish are resistant to water with low quality or poor water quality, even catfish can live in very low oxygen conditions, because they have a breathing apparatus in the form of an arborescent, that can take oxygen directly from the air. Budikdamber or Fish Cultivation in Buckets was first introduced by Juli Nursandi who is a Lecturer in Fisheries Cultivation at the Lampung State Polytechnic ${ }^{21}$. Budikdamber can be used to cultivate a variety of freshwater fish, such as; catfish, tilapia, carp, catfish, and sepat fish. This method not only cultivating fish, but it can be used to grow water spinach. These vegetables were chosen because they are easy to cultivate, low prices, and fast harvesting 22 . The previous research related to Fish Cultivation in Buckets is as follows:

1. Research conducted by Asep Agus Handaka, Lantun Paradhita Dewanti, and Aulia Andhikawati with the title of "Counseling Support of Fish Cultivation in Buckets (Budikdamber) at Sukapura Village, Dayeuhkolot District, Bandung Regency" in 2021, mentioned that Budikdamber might be an alternative business that can be carried out to maintain fishery food security ${ }^{23}$. Budikdamber is also able to increase community income during the Covid-19 pandemic. Budikdamber with Cultivating the catfish in buckets with an aquaponic system has advantages such as easy to practice, cheap, saves water, does not

\footnotetext{
16 Purnaningsih et al., "Diseminasi Budidaya Ikan Dalam Ember Sebagai Solusi Kegiatan Budidaya Di Lahan Sempit ( Dissemination of Aquaculture in The Buckets as Solutions for Cultivation Activities in Narrow Lands )."

17 Ibid.

${ }^{18}$ Annis, Saputri, and Rachmawatie, "Budidaya Ikan Dalam Ember: Strategi Keluarga Dalam Rangka Memperkuat Ketahanan Pangan Di Tengah Pandemi Covid-19 Fish Culture in a Bucket: Family Strategy in Order to Strengthen Food Security in the Covid-19 Pandemic Period."

19 Ibid.

${ }^{20}$ Ibid.

${ }^{21}$ Nur Rohmi Aida, "Viral Video Budikdamber, Pelihara Ikan Dan Tanam Sayur Di Ember, Ini Cerita Penemunya," Kompas.Com, May 4, 2020,

https://www.kompas.com/tren/read/2020/05/04/084700065/viral-video-budikdamber-pelihara-ikandan-tanam-sayur-di-ember-ini-cerita?page=all.

${ }^{22}$ Bejo Suroso and Antoni Novi Eko Rivo, "Respon Pertumbuhan Tanaman Kangkung Darat (Ipomoea Reptans Poir) terhadap Pupuk Bioboost dan Pupuk ZA," Journal of Agricultural Science 14, No. 1 (2016): 98-108, Http://Jurnal.Unmuhjember.Ac.Id/Index.Php/AgritroP/article/view/417/310.

${ }^{23}$ Asep Agus Handaka Suryana, Lantun Paradhita Dewanti, and Aulia Andhikawati, "Counseling on Fish Cultivation in Buckets (Budikdamber) in Sukapura Village, Dayeuhkolot District, Bandung Regency," Farmers: Journal of Community Services 2, no. 1 (2021): 47-51, https://jurnal.unpad.ac.id/fjcs/article/view/31547.
} 
require large land, and is economical so that this activity becomes a potential for the resident in Sukapura Village in an effort to maintain food security independently. The Budikdamber activity was one way to educate the surrounding community that was held virtually. The output of the program was the society in Sukapura Village who became more educated about Budikdamber in order to maintain independent food security in the Covid-19 pandemic ${ }^{24}$.

2. Research conducted by Putu Shantiawan Prabawa, Made Suarsana, and I Putu Parmila in 2021 regarding "Budikdamber Training as an Effort to Maintain Family Food Security in Banyuasri Buleleng Villagers", which used combination method of counseling, coaching, and direct assistance in order to help residents to understand the material ${ }^{25}$. Residents are very enthusiastic about participating in this activity. The results of this study were able to provide additional knowledge to local residents regarding strategies for maintaining food security during the Covid-19 pandemic. Furthermore, the results of the assistance and field monitoring found that the condition of the dead fish was caused by delays in feeding. However, the low fish mortality report indicates that the transfer of knowledge and technology through community service programs is running optimally. At the end of the activity the community service team also provided Budikdamber tools and materials so that residents could practice independently in their homes.

3. Deni Irfayanti and Putri Wahyu Ningsih in their research entitled "Food Independence by Making Budikdamber (Fish Cultivation in Buckets) in Telanaipura District, Jambi City" 2020, stated that the results of Budikdamber can be used to fulfill household food needs that can support economic conditions local community ${ }^{26}$. This Budikdamber is also suitable for community who have difficulties to fulfill their food independently during the Covid-19 pandemic. In addition to aiming for food security, Budikdamber can also strengthen a sense of togetherness and create a culture of mutual cooperation in the community.

4. Research conducted by Rr Retno Sugiharti, Dhanes Noor Viana, and Nibras Anny Khabibah in 2020, entitled "Budikdamber (Cultivation of Plants and Fish In Bucket) to Support the Organic Village Program in Dumpoh Kampung Village Magelang City" stated that the residents of Dumpoh Village became independent in terms of food and environmentally conscious ${ }^{27}$. Practice is carried out to provide guidance on cultivation steps in narrow areas using the Budikdamber method. Assistance is provided in the management of Budikdamber for sustainable harvests. This activity was expected for the community will be able to cultivate independently. From the harvested products, entrepreneurship training is also provided for marketing and calculating business profits to increase household income. The implementation of the Community Partnership Program is carried out using classical/ lecture methods, tutorials, practices, and discussions. Dumpoh Village residents are becoming food-independent citizens who are environmentally conscious by this Community Partnership Program activities. The results of his research showed that insight and knowledge of local residents about household food security were increased.

\footnotetext{
${ }^{24}$ Ibid.

25 Putu Shantiawan Prabawa, Made Suarsana, and I Putu Parmila, "Pelatihan Budikdamber sebagai Upaya Menjaga Ketahanan Pangan Keluarga pada Warga Kelurahan Banyuasri, Buleleng," BERNAS: Jurnal Pengabdian Kepada Masyarakat 2, no. 1 SE-Articles (January 4, 2021), https://ejournal.unma.ac.id/index.php/bernas/article/view/717.

${ }^{26}$ Deni Irfayanti and Putri Wahyu Ningsih, "Kemandirian Pangan dengan Pembuatan Budikdamber (Budidaya Ikan dalam Ember) di Kecamatan Telanaipura Kota Jambi," Jurnal Pembelajaran Pemberdayaan Masyarakat 1, no. 4 (2020): 350-355,

http://riset.unisma.ac.id/index.php/JP2M/article/view/8815/7645.

${ }^{27}$ Rr. Retno Sugiharti, Dhanes Noor Viana, and Nibras Anny Khabibah, "Budikdamber (Budidaya Tanaman dan Ikan dalam Ember) untuk Mendukung Program Kampung Organik di Kampung Dumpoh Kota Magelang," Civitas Ministerium Jurnal Pengabdian Kepada Masyarakat Fakultas Teknik Universitas Tidar 4, no. 1 (2020), https://jurnal.untidar.ac.id/index.php/civitasministerium/article/view/3458.
} 
5. Research conducted by Husna Ni'matul Ulya entitled "East Java Economic Recovery during the Covid-19 Pandemic through the Budikdamber Integrated Agricultural System (Fish Cultivation in Buckets)" stated that the decline in Indonesia's economic growth during the Covid-19 pandemic occurred during the first quarter and second quarter ${ }^{28}$. It was caused a weakening of the economy and decreased people's income. Due to government policies to prevent the spread of Covid-19, people must stay at home and reduce outdoor activities. Among the sectors that have experienced a decline, the agricultural sector is still experiencing positive growth. This was caused by the productivity of the agricultural sector is not significantly affected by the pandemic situation, but the problem is that the amount of demand is decreasing more than before. Budikdamber is an option to fulfill an integrated agricultural system. Its was used to utilizing existing resources and it can also maximize the use of the same media for two cultivation systems. However, much remains to be done to follow up on the development of this system in line with the demands of social, cultural, technological, and economic development in society ${ }^{29}$.

\section{Research Method}

This research was carried out for about 2 (two) months from March to April 2021. Socialization and training on how to utilize narrow space through Budikdamber was carried out to 15 (fifteen) residents who lived in alley 8 number 88, Simomulyo Baru Village, sub-district Sukomanunggal Surabaya city as shown in Figure 1 . The tools and materials needed in this study as shown in Figure 2 include catfish seeds, water spinach seeds, coconut shell charcoal, 80 liter bucket/barrel, plastic cups, waterproof tissue, duct tape, catfish feed, solder, wire, pliers, and hose.

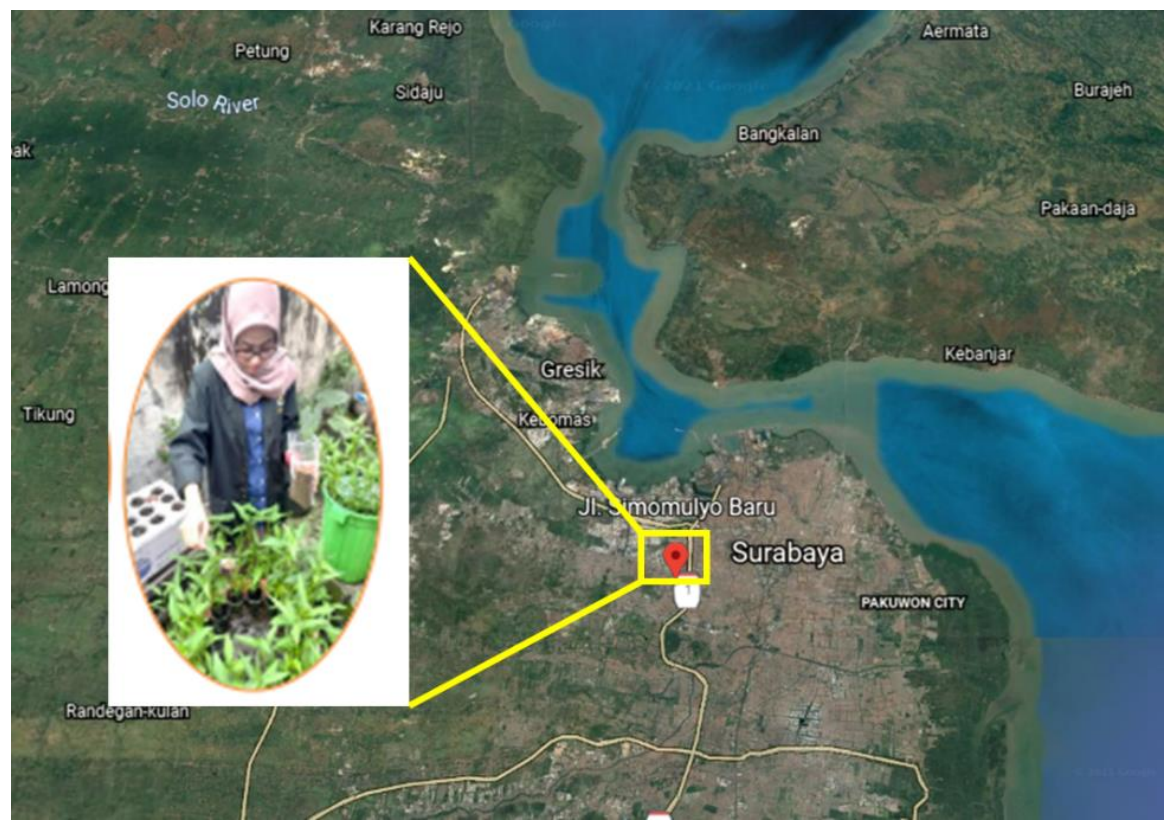

Figure 1 Project location

Source: Map obtained from Google Earth, accessed on October 18, 2021

\footnotetext{
${ }^{28}$ Husna Ni'matul Ulya, "Pemulihan Perekonomian Jawa Timur Di Masa Pandemi Covid-19 Melalui Sistem Pertanian Terpadu (SPT) Budikdamber (Budidaya Ikan Dalam Ember)," JoIE: Journal of Islamic Economics 1, no. 1 (2021): 41-66, https://jurnal.iainponorogo.ac.id/index.php/joie/article/view/3085.

${ }^{29}$ Ibid.
} 


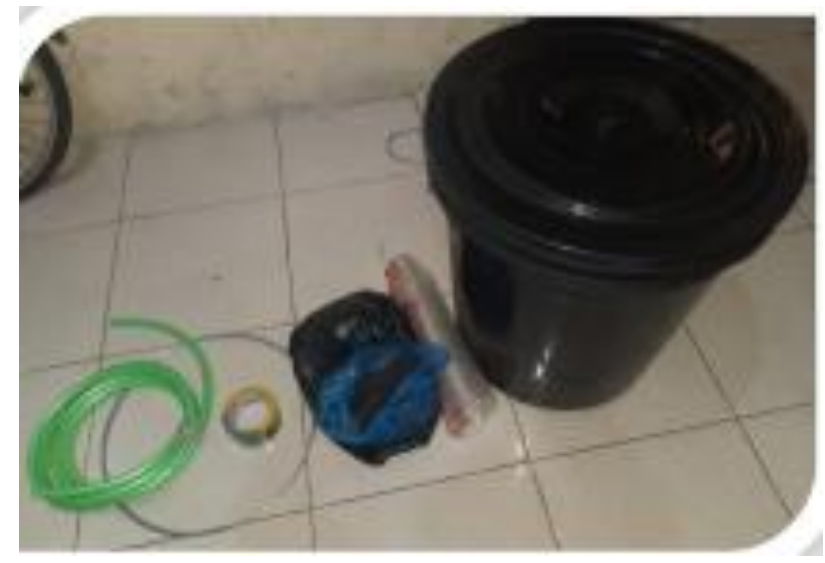

Figure 2 Tools and materials needed for Budikdamber (bucket, hose, plastic cup, wire)

Step by step techniques for making Budikdamber as shown in Figure 3 as follows: 1) preparing vegetable planting media, 2) punching 10 plastic cups with soldering iron, 3) cutting the water spinach plant and left over the bottom part, 4) inserting the water spinach into the glass, 5 ) the glass is filled with coconut shell charcoal between 50 and 80 percent of the size of the glass, 6) cutting the wire to approximately $12 \mathrm{~cm}, 7$ ) making hook model as a glass holder on a bucket. Next is the preparation of the media for Budikdamber, including: 1) Filling the bucket with 60 liters of water and allowed to stand for approximately 1 to 2 days, 2) putting catfish seeds in a bucket, 3) Assembling a glass of water spinach and placed on the edge of the bucket.

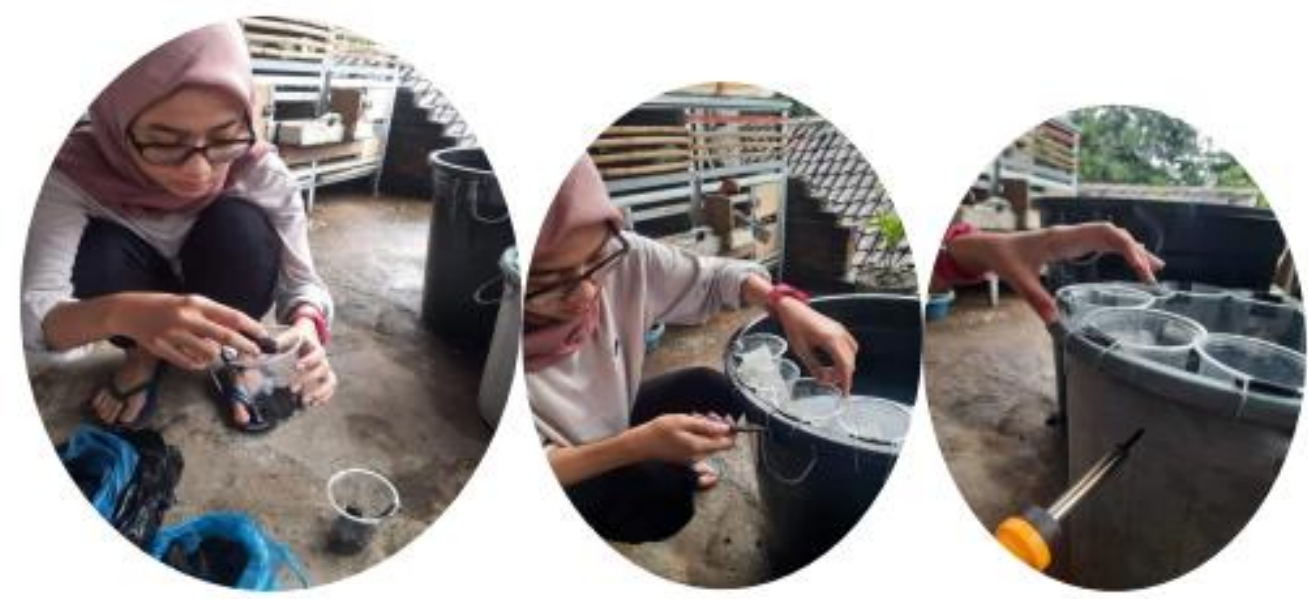

Figure 3 The process of making Budikdamber. (left) filling a glass with charcoal and tissue; (middle) hooking the glass into the bucket and (right) punching holes in the bucket with solder

\section{Results and Discussion}

The increasing population growth from year to year has conversed land into a housing complex or other functions. The lack of remaining pages has made the land for fish cultivation and agriculture increasingly limited while the demand for vegetable and animal protein continues to grow. In this regard, the technique of Cultivating Fish in Buckets (Budidaya Ikan dalam Ember - Budikdamber) becomes a potential alternative for the community to maximize the remaining land for fish cultivation and agriculture with more efficient use of water. Budikdamber can be easily carried out by the community in their respective houses with relatively small capital, eventually enabling them to meet their nutritional needs. In addition, like "killing two birds with one stone", Budikdamber is also a complete way to cultivate fish and 
vegetables in the same medium, namely buckets. The work system of Budikdamber is cultivating fish and vegetables in one bucket which is almost similar to an aquaponics system (polyculture of fish and vegetables). The difference is that Budikdamber is not as complicated as aquaponics with pumps and filters which require electricity, large land, much cost, and a more complicated system.

Some advantages of Budikdamber are the efficient use of water, zero waste, easy maintenance, and no use of chemicals. Not all fish can be cultivated with the Budikdamber technique. Only fish that can tolerate low oxygens are suitably cultivated with the Budikdamber technique, such as catfish. Meanwhile, the type of plants that can be grown depends on the type of media used. Vegetables such as water spinach (kangkung) can be grown using this technique with charcoal media. Maintenance for Budikdamber is not difficult but takes consistency in the following steps:

1. Place the bucket in a place exposed to maximum sunlight.

2. Kangkung will be seen growing on the third day.

3. Remove immediately the Kangkung leaves or stems if there are lice on the leaves (lice can make kangkung curl and die).

4. Feed the fish as much as they want (it can be given 2-3 times at a fixed time).

5. Replace the water or siphon (suction the dirt at the bottom of the bucket with a hose), usually once every 10-14 days. If the fish's appetite decreases, the water smells bad (NH3, H2S) and the fish hang with head up and tail below.

6. The suction can be $50-80 \%$ of the total water or can be entire if needed.

7. Then, replace it with clean water.

8. Add water up to the neck of the bucket because enlarged kangkung requires more water.

When routine maintenance has been carried out, the maximum yields at the harvest stage can be achieved. The procedure for harvesting the yields of this Budikdamber technique is as follows:

1. The first harvest of kangkung is 14-21 days from planting (Figure 4).

2. The bottom of the kangkung shoots is left for regrowth.

3. The second and subsequent harvests are 10-14 days apart (once every 10-14 days).

4. Catfish can be harvested in 2 months only if the seeds and feed are good.

5. The survival rate of the catfish is $40-100 \%$.

6. Catfish can be harvested by scooping or draining.
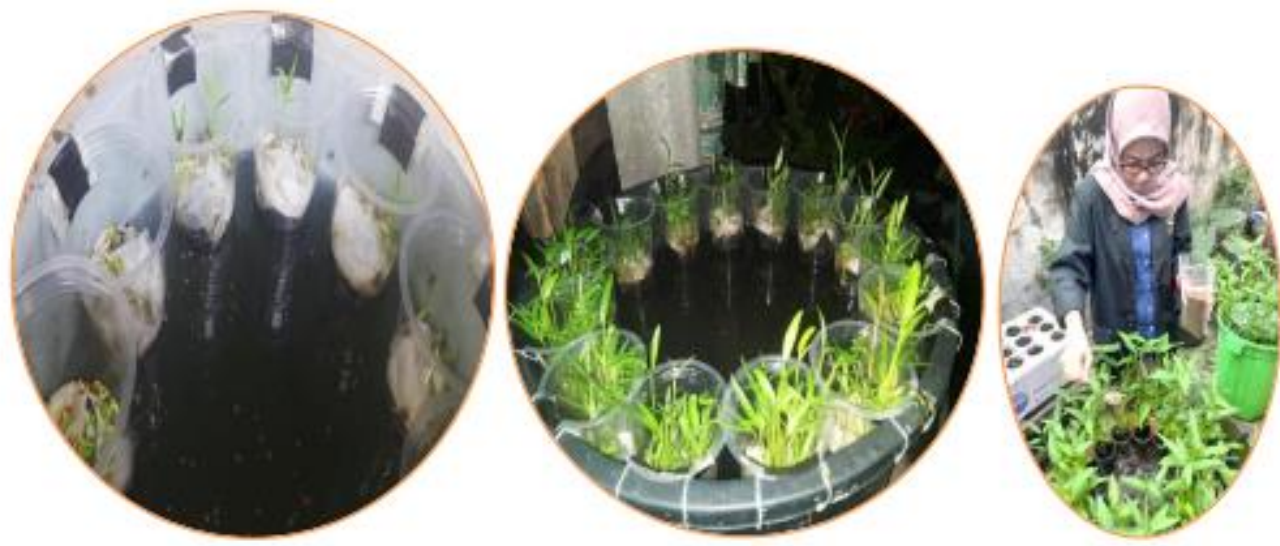

Figure 4 The growth of Kangkung in 6 days (left), 2 weeks (center), and 1 month (right)

The best way to harvest kangkung is to leave the most bottom two leaves on the stem, on which new kangkung leaves will grow. This way of harvesting kangkung can only be applied a few times to keep producing good quality kangkung. Kangkung with poor quality is shown in 
Figure 5. Meanwhile, catfish that has reached a suitable size for consumption must be immediately separated from the cultivation bucket.

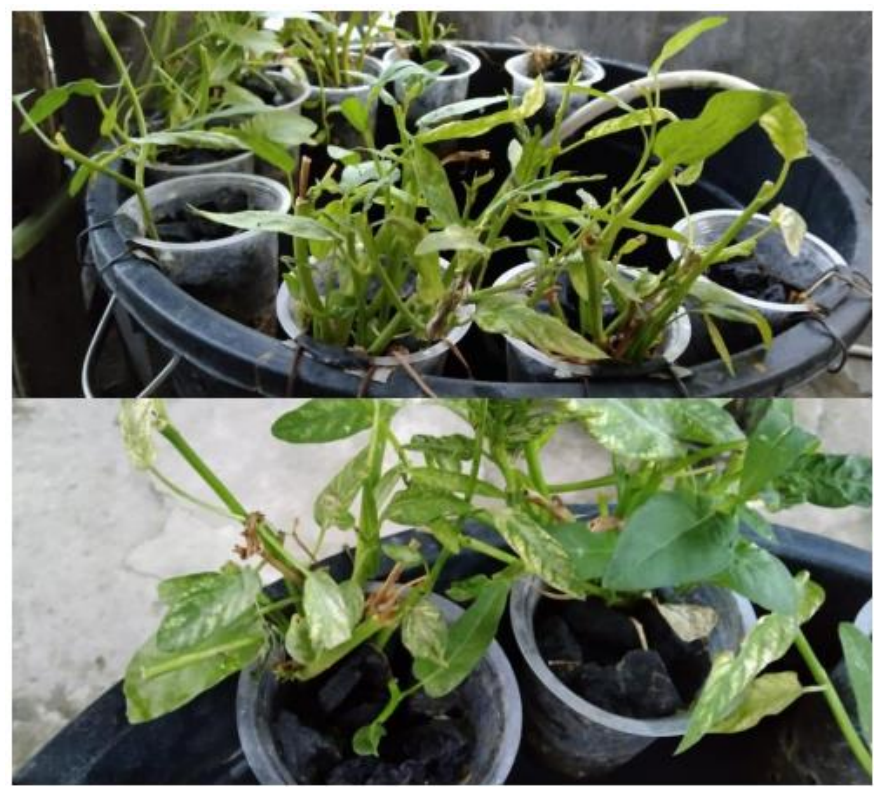

Figure 5 Less-quality Kangkung (Requiring a New Nursery)

The people living in Alley 8 No. 88, Simomulyo Baru Subdistrict, Sukomanunggal District, Surabaya City have known Budikdamber technology and have felt the direct benefits obtained. The application of Budikdamber is a food security strategy at the family level during the Covid19 pandemic so that the people can live independently and spend time with useful things during the social restriction. As found in previous studies, the other benefit of the application of Budikdamber is that the yields of fish cultivation and agriculture can be consumed at a low cost. In other words, people can save money without reducing their food nutritional needs. Besides, the process of Budikdamber is protected from environmental pollution, for example, waste contained in water bodies (rivers, lakes, and others). Due to limited land in big cities, kangkung is often planted in rivers or gullies with blackish water color containing a lot of pollutants. Budikdamber is proven to provide benefits for the people living in Alley 8 No. 88, Simomulyo Baru Subdistrict, Suomanunggal District, Surabaya City.

\section{E. Conclusion}

The technique of Cultivating Fish in Buckets (Budidaya Ikan dalam Ember-Budikdamber) becomes a potential alternative for the community to maximize the remaining land for fish cultivation and agriculture with more efficient use of water. Budikdamber can be easily carried out by the community in their respective houses with relatively small capital, eventually enabling them to meet their nutritional needs. This is suitable for urban areas with minimal land and it is easy to apply in respective house with low budget, which finally able to meet their nutritional needs of Simomulyo Baru Village community. The socialization and training of Budikdamber given to 15 (fifteen) people living in Alley 8 No.88, Simomulyo Baru Subdistrict, Sukomanunggal District, Surabaya City showed that the people of Simomulyo have felt the benefits of Budikdamber since they can harvest fish and vegetables any time at harvest time. Economically, it can help reduce daily household costs and maintain the community's food security. The researcher hopes that Budikdamber can be carried out consistently and expanded from only 5 Family Cards to one Neighborhood Unit $(R T)$ or Community Unit $(R W)$. One of the long-term benefits of Budikdamber is to produce fish and vegetables that can be traded by and 
for the community. Furthermore, the community can to together develop it as a Micro, Small and Medium Enterprise.

\section{References}

Agus Handaka Suryana, Asep, Lantun Paradhita Dewanti, and Aulia Andhikawati. "Counseling on Fish Cultivation in Buckets (Budikdamber) in Sukapura Village, Dayeuhkolot District, Bandung Regency." Farmers: Journal of Community Services 2, no. 1 (2021): 47-51. https://jurnal.unpad.ac.id/fjcs/article/view/31547.

Aida, Nur Rohmi. "Viral Video Budikdamber, Pelihara Ikan Dan Tanam Sayur Di Ember, Ini Cerita Penemunya." Kompas.Com, May 2020. https://www.kompas.com/tren/read/2020/05/04/084700065/viral-video-budikdamberpelihara-ikan-dan-tanam-sayur-di-ember-ini-cerita?page=all.

Annis, Sherina, Dewi Saputri, and Dessy Rachmawatie. "Budidaya Ikan Dalam Ember: Strategi Keluarga Dalam Rangka Memperkuat Ketahanan Pangan Di Tengah Pandemi Covid-19 Fish Culture in a Bucket: Family Strategy in Order to Strengthen Food Security in the Covid-19 Pandemic Period" 2, no. 1 (2020): 102-109.

Enggar Susetya, Ipanna, and Zulham Apandy Harahap. "Aplikasi Budikdamber (Budidaya Ikan Dalam Ember) untuk Keterbatasan Lahan Budidaya Di Kota Medan." ABDIMAS TALENTA: Jurnal Pengabdian Kepada Masyarakat 3, no. 2 (2018): 416-420. https://talenta.usu.ac.id/abdimas/article/view/4165.

Enloe, Autumn. "The 13 Healthiest Leafy Green Vegetables." Last modified 2018. Accessed September 2, 2021. https://www.healthline.com/nutrition/leafy-green-vegetables.

Hall, R A, G M Meaburn, E G Zook, and United States. "National Marine Fisheries Service Survey of Trace Elements in the Fishery Resources." NOAA technical report;NMFS SSRF-721. Rockville, Md.: Dept. of Commerce, National Oceanic and Atmospheric Administration, National Marine Fisheries Service, 1978. file://catalog.hathitrust.org/Record/102424037.

Irfayanti, Deni, and Putri Wahyu Ningsih. "Kemandirian Pangan dengan Pembuatan Budikdamber (Budidaya Ikan dalam Ember) di Kecamatan Telanaipura Kota Jambi." Jurnal Pembelajaran Pemberdayaan Masyarakat 1, no. 4 (2020): 350-355. http://riset.unisma.ac.id/index.php/JP2M/article/view/8815/7645.

Joseph, Michael. "Catfish 101: Nutrition Facts and Health Benefits." Last modified 2019. Accessed September 2, 2021. https://www.nutritionadvance.com/catfish-nutrition-benefits/.

Ni'matul Ulya, Husna. "Pemulihan Perekonomian Jawa Timur di Masa Pandemi Covid-19 Melalui Sistem Pertanian Terpadu (SPT) Budikdamber (Budidaya Ikan Dalam Ember)." JoIE: Journal of Islamic Economics 1, no. 1 (2021): 41-66. https://jurnal.iainponorogo.ac.id/index.php/joie/article/view/3085.

Prabawa, Putu Shantiawan, Made Suarsana, and I Putu Parmila. "Pelatihan Budikdamber sebagai Upaya Menjaga Ketahanan Pangan Keluarga pada Warga Kelurahan Banyuasri, Buleleng." BERNAS: Jurnal Pengabdian Kepada Masyarakat 2, no. 1 SE-Articles (January 4, 2021). https://ejournal.unma.ac.id/index.php/bernas/article/view/717.

Purnaningsih, Ninuk, Thouriqul Ihsan, Budi Tryantono, and Reyfan Almer. "Diseminasi Budidaya Ikan Dalam Ember Sebagai Solusi Kegiatan Budidaya Di Lahan Sempit ( Dissemination of Aquaculture in The Buckets as Solutions for Cultivation Activities in Narrow Lands )" 2 (2020): 112-120.

Sugiharti, Rr. Retno, Dhanes Noor Viana, and Nibras Anny Khabibah. "Budikdamber (Budidaya Tanaman dan Ikan Dalam Ember) untuk Mendukung Program Kampung Organik di 
Kampung Dumpoh Kota Magelang." Civitas Ministerium Jurnal Pengabdian Kepada Masyarakat Fakultas Teknik Universitas Tidar 4, no. 1 (2020). https://jurnal.untidar.ac.id/index.php/civitasministerium/article/view/3458.

Suroso, Bejo, and Antoni Novi Eko Rivo. "Respon Pertumbuhan Tanaman Kangkung Darat (Ipomoea Reptans Poir) terhadap Pupuk Bioboost dan Pupuk ZA." Journal of Agricultural $\begin{array}{lllll}\text { Science } & 14, & \text { no. } & 1 & \text { (2016): }\end{array}$ http://jurnal.unmuhjember.ac.id/index.php/AGRITROP/article/view/417/310.

Syaifariz, Akbar, Achmad Aris Nursidik, Nabila Khusnul Khotimah, and Moh Tedo Khairun. "Budikdamber sebagai Stategi Penguatan Ketahanan Pangan dan Perekonomian Masyarakat Kabupaten Brebes di Tengah Pandemi” (n.d.).

Wicaksono, Adhi. "Kemenaker Sebut 2,9 Juta Pekerja Dirumahkan Dan Kena PHK." CNN Indonesia, May 1, 2021. https://www.cnnindonesia.com/ekonomi/20200501182722-92499300/kemenaker-sebut-29-juta-pekerja-dirumahkan-dan-kena-phk.

Kecamatan Sukomanunggal Dalam Angka 2019. Surabaya, 2019.

Mercury Levels in Commercial Fish and Shellfish (1990-2012). Silver Spring, Maryland, 2014. https://www.fda.gov/food/metals-and-your-food/mercury-levels-commercial-fish-andshellfish-1990-2012.

“Peta Dan Visualisasi Data Covid-19." Last modified 2021. Accessed August 5, 2021. https://lawancovid-19.surabaya.go.id/.

$\begin{array}{llllll}\text { Statistik Sektoral Kota } & \text { Surabaya } & 2017 . & \text { Surabaya, }\end{array}$ https://www.surabaya.go.id/id/berita/49832/statistik-sektoral-kota-surabaya.

\section{Acknowledgment}

We thank our colleagues from Islamic Community Development UIN Sunan Ampel Surabaya, who helped for data collection that greatly assisted this research. 